\title{
Prolactin Response to $d l$-Fenfluramine Challenge before and after Treatment with Paroxetine
}

\author{
Michael C. Dulchin, M.D., Maria A. Oquendo, M.D., Kevin M. Malone, M.D., \\ Steven P. Ellis, Ph.D., Shuhua Li, Ph.D., and J. John Mann, M.D.
}

\begin{abstract}
The prolactin response to dl-fenfluramine (an indirect central serotonin agonist) challenge has been used to assess serotonergic function and appears to be blunted in depressed patients. We used this method to determine whether the serotonergic deficit in depressed patients is corrected by treatment with paroxetine. Prior to treatment with paroxetine sixteen depressed patients received a placebo challenge followed by a dl-fenfluramine challenge the next day. The same two challenges were repeated after treatment. Prolactin baseline levels were measured before pill administration, and then hourly for 5 hours. Fenfluramine/ norfenfluramine levels were assayed at each time point after drug administration. Treatment with paroxetine significantly increased the baseline prolactin level
\end{abstract}

independently of treatment response but positively correlated with paroxetine dose. We found that pre-treatment prolactin response to dl-fenfluramine challenge did not predict clinical response to paroxetine, nor did the prolactin response change significantly after treatment. There was no significant difference in the post-treatment prolactin response between treatment responders and treatment non-responders. We found evidence of increased prolactin levels that may reflect effects of paroxetine in enhancing serotonin levels. Acute release of serotonin as measured by the prolactin response to fenfluramine is not altered by paroxetine treatment.

[Neuropsychopharmacology 25:395-401, 2001] (C) 2001 American College of Neuropsychopharmacology. Published by Elsevier Science Inc.
KEY WORDS: Fenfluramine challenge; Serotonin; Depression; Pharmacologic treatment; paroxetine

Disturbed serotonin function in Major Depression has been evident from in vivo challenge studies of serotonin responsivity using clomipramine (Leatherman et al. 1993), tryptophan (Charney et al. 1984), ipsapirone (Lesch 1991), m-chlorphenylpiperazine (mCPP) (Quested et al. 1997), 1-5 hydroxytryptophan (Maes and Meltzer 1995), and fenfluramine (Mann et al. 1995, 1996; Siever

From the Center for Study of Suicidal Behavior, Department of Neuroscience, New York State Psychiatric Institute, 1051 Riverside Drive, New York, NY 10032.

Address correspondence to: Michael Dulchin MD, New York State Psychiatric Institute, Box \# 105, 1051 Riverside Drive, New York, NY 10032.

Received June 16, 2000; revised February 5, 2001; accepted February 14, 2001.

Online publication: 2/13/01 at www.acnp.org/citations/Npp 02140180. et al. 1984; Shapira et al. 1993, 1992a,b; Kasper et al. 1990; Flory et al. 1998; Malone et al. 1996; Mokrani et al. 1997).

Fenfluramine (both $d$ and $d l$ ) is an indirect central serotonin agonist that both inhibits serotonin reuptake and causes its release from presynaptic storage granules. Its metabolite norfenfluramine may have a direct effect on postsynaptic receptors (Mann et al. 1995; McBride et al. 1990). Most (Mann et al. 1995; Coccaro et al. 1989; Lichtenberg et al. 1992; Mitchell and Smythe 1990; O'Keane and Dinan 1991; Lopez-Ibor et al. 1988), but not all (Weizman et al. 1988; Asnis et al. 1988; Park et al. 1996) studies using either $d$-fenfluramine or $d l$-fenfluramine challenge have found a blunting of prolactin response in patients with Major Depression.

Post-treatment prolactin response to challenge has been found to be enhanced by antidepressant treatment by some groups (O'Keane and Dinan 1991; Shapira et al. 1989, 1992a,b; Leatherman et al. 1993), but not others (Kasper et al. 1990). Leatherman et al. (1993), using a 
clomipramine challenge, also found greater post-treatment enhancement in prolactin response in clinical responders to treatment as compared to non-responders. However, most studies (Kasper et al. 1990; Shapira et al. 1992b; O'Keane et al. 1992) do not find this difference between responders and non-responders.

While a number of studies using the fenfluramine challenge (Cleare et al. 1998; Kasper et al. 1990; Park et al. 1995; Shapira et al. 1992a) have tried to determine whether markers of serotonergic dysfunction obtained prior to treatment could be used to predict response to treatment, only ours (Malone et al. 1993) found that treatment response could be predicted. This study demonstrated that a more robust pre-treatment prolactin response to fenfluramine challenge predicted a better clinical response to treatments that affected both the serotonergic and noradrenergic systems.

We hypothesized in this current study that a more robust pre-treatment prolactin response would even better predict clinical response to the primarily serotonergic agent paroxetine. We further hypothesized that the subset of patients who responded clinically to the SSRI paroxetine would have a more robust prolactin response after treatment, compared to before treatment and compared to clinical non-responders.

\section{METHODS AND MATERIALS}

\section{Subjects}

Sixteen $(N=16)$ subjects requiring treatment for an episode of Major Depression were entered into the study after giving written informed consent as required by the Institutional Review Board. All subjects were diagnosed using a structured clinical interview (SCID I for DSM III-R) (Spitzer et al. 1989) and had a score of 16 or more on the 17-item Hamilton Depression Rating Scale (HDRS). All subjects had been free of antidepressants, antipsychotics and other medication known to affect serotonergic function for at least two weeks (4 weeks for oral anti-psychotics, 6 weeks for fluoxetine). Significant medical illness was excluded by medical history, physical examination and routine laboratory testing. Patients with current substance or alcohol abuse were excluded.

\section{Procedure}

Subjects had two challenges, each on separate days before the commencement of treatment. The first challenge was with placebo, and the second, the following day, with approximately $0.8 \mathrm{mg} / \mathrm{kg}$ of $d l$-fenfluramine orally. The capsules were identical and given single blind. On each challenge day, subjects in a fasting state had an intravenous catheter placed at about 8 AM. They received the challenge agent at $9 \mathrm{AM}$.
Blood samples were drawn 15 min before capsule administration (time -15), at time of administration of the capsule (time 0 ) and then hourly for 5 hours. These samples were analyzed for prolactin, fenfluramine, and norfenfluramine levels. Subjects were subsequently treated with only paroxetine for a minimum of 4 weeks. Paroxetine dose was adjusted clinically, taking into account the patient's ability to tolerate the medication and treatment response. Patients who responded to paroxetine were then studied for a second time using the same protocol as described above. Patients who did not respond to paroxetine were restudied before changing the treatment to a different medication. All patients had HDRS ratings within one week of the repeat challenges. Premenopausal female subjects were studied two days after the onset of their menstrual period.

\section{Statistical Analysis}

All data are reported as mean \pm SD unless otherwise indicated. Responders to treatment were defined as those with a greater than $50 \%$ reduction in HDRS. Prolactin response to challenge was defined as follows: the maximum prolactin level during hours 2 through 5 minus the baseline prolactin level. Baseline was defined as the mean of the prolactin values at 6 time points: $-15,0$, and 1 on both active and placebo days. We decided to use six time points because the challenges were done only one day apart and at the same hour of the day. This way, we hoped to minimize the effects of "noise," such as IV insertion 1 hour prior to blood draw or novel environment, on baseline prolactin.

We used log transformations of the prolactin levels to insure a normal distribution of the values. To assess whether pre-treatment response to fenfluramine challenge could predict clinical response, a logistic regression was conducted with clinical response as the dependent variable and pre-treatment prolactin response to fenfluramine challenge, age, and sex as independent variables. This analysis was also done with dose of paroxetine added as an independent variable. To determine whether post-treatment prolactin response to fenfluramine challenge was dependent on clinical response, a linear model with post-treatment prolactin as the dependent variable and response to treatment, age, sex, and dose of paroxetine as the independent variables was used.

To assess whether paroxetine treatment had an effect on baseline prolactin levels, a mixed model was utilized with the baseline prolactin levels as the dependent variable and phase of study (pre-treatment vs. post-treatment), sex, age, paroxetine dose, hour post challenge and active fenfluramine versus placebo condition as the independent variables. The difference between prolactin response to fenfluramine challenge prior to treatment and the prolactin response to fenfluramine chal- 
lenge after treatment with paroxetine was examined using a mixed model with prolactin response to fenfluramine challenge as the dependent variable and with phase of study (pre-treatment vs. post-treatment), age, sex, dose of paroxetine and treatment with paroxetine as the independent variables.

\section{RESULTS}

The study subjects included eight men and eight women. Seven patients were classified as responders (HDRS decreased by $50 \%$ or greater), 14 patients had unipolar depression, and two had bipolar depression. All 16 patients were diagnosed with unipolar depression at the time of the study, however, two of the patients were re-diagnosed with bipolar disorder on follow up interview one year later. Mean age was $42 \pm$ 11.0 years. Responders and non-responders did not differ in terms of age, sex, diagnosis, or inpatient status. There was a trend $(p=.069)$ for non-responders to be on a higher dose of paroxetine $(55.6 \pm 15.1 \mathrm{mg})$ compared to responders $(38.6 \pm 19.5 \mathrm{mg})$. Mean duration of treatment with paroxetine for all subjects was $65.9 \pm$ 32.1 days. Non-responders were treated for a mean of $71.4 \pm 31.2$ days. This difference between responders and non-responders was not significant $(p=.451)$.

Relationship between Clinical Response and Pre-treatment Prolactin Response to Fenfluramine. Clinical responders and non-responders were not significantly different in terms of baseline HDRS or fenfluramine plus norfenfluramine levels at the time of highest prolactin level both pre-treatment $(60.6 \pm 20.6 \mathrm{ng} / \mathrm{ml})$ and post-treatment $(67.8 \pm 22.3 \mathrm{ng} / \mathrm{ml})$. Pre-treatment prolactin response to fenfluramine did not predict response status when age and sex were controlled for $(p=0.31$, Wald confidence limits 0.005 to 5.521), nor when paroxetine dose was controlled for in addition ( $p=.49$, Wald confidence limits 0.005 to 12.324).

Relationship between Clinical Response and Posttreatment Prolactin. Response to Fenfluramine. Clinical response to treatment did not predict prolactin response to fenfluramine after treatment (responders: $6.3 \pm$ $7.6 \mathrm{ng} / \mathrm{ml}$, non-responders: $17.1 \pm 10.9 \mathrm{ng} / \mathrm{ml}$ ) when age, sex, and dose of paroxetine were controlled for $(p<.200)$. Prolactin response to fenfluramine was more robust in females $(p=.025)$ and at higher doses of paroxetine $(p=.048)$.

Effects of Paroxetine Treatment on Baseline Prolactin. Baseline prolactin levels were significantly higher after paroxetine treatment $(\mathrm{df}=1,181, \mathrm{~F}=9.19, p=.003)$. The baseline prolactin level prior to treatment was $7.9 \pm 2.4$ $\mathrm{ng} / \mathrm{ml}$ and increased to $9.6 \pm 4.1 \mathrm{ng} / \mathrm{ml}$. The covariates that showed significant effects were sex (women had greater baseline prolactin than men, $p=.040$ ), age (baseline prolactin level decreased with age, $p=.025)$, and dose of paroxetine (baseline prolactin level increased after treatment with paroxetine but increasing paroxetine dose was associated with a lesser magnitude of increased response $(\mathrm{df}=1,181, \mathrm{~F}=19.63, p=.0001)$.

Effects of Paroxetine Treatment on Prolactin Response to Fenfluramine. There was no significant change in the prolactin response to fenfluramine challenge after treatment (pre-treatment: $10.2 \pm 7.2 \mathrm{ng} / \mathrm{ml}$; post-treatment: $12.4 \pm 10.8 \mathrm{ng} / \mathrm{ml})$ with paroxetine $(\mathrm{df}=1,27, \mathrm{~F}=$ $2.57, p=.121$ ). The prolactin response was not associated with age $(\mathrm{df}=1,27, \mathrm{~F}=2.52, p=.124)$. As expected, a significant interaction was found for $\operatorname{sex}(\mathrm{df}=$ $1,27, \mathrm{~F}=12.73, p=.001$ ) in that women had a more robust response than men. A significant interaction was also found for paroxetine dose ( $\mathrm{df}=1,27, \mathrm{~F}=6.81, p=$ .015 ) in that as dose of paroxetine increased prolactin response to fenfluramine did also.

\section{DISCUSSION}

Paroxetine treatment increases the baseline plasma prolactin but not the response to fenfluramine challenge. Pre-treatment prolactin response to fenfluramine challenge does not predict clinical response to paroxetine treatment in this sample. In addition, post-treatment prolactin response to fenfluramine is not different in clinical responders and non-responders. This is the first investigation to our knowledge to evaluate the effect of paroxetine treatment and clinical response on central serotonergic function assessed by fenfluramine challenge.

\section{Effects of Paroxetine Treatment on Baseline Prolactin}

Our study is consistent with previous studies on paroxetine's effect on baseline prolactin. Cowen and Sargent (1997) and Wing et al. (1996) both showed that paroxetine significantly increases baseline plasma prolactin in healthy volunteers. Studies of other SSRI's and other anti-depressants have shown inconsistent effects on baseline prolactin levels.

Some studies have reported that citalopram (Laine et al. 1997), fluoxetine (Urban and Veldhuis 1991), and fluvoxamine (Spigset and Mjörndal 1997) increase baseline prolactin levels. Sertraline, however, was found by Gordon et al. (1998) to cause no increase in baseline prolactin in healthy volunteers. Other studies have shown decreases in baseline prolactin after two weeks of treatment with fluoxetine (Sommers et al. 1994). 


\section{Effects of Paroxetine Treatment on Prolactin Response to Fenfluramine}

There are conflicting results with regard to change in prolactin response to fenfluramine challenge after antidepressant treatment. Kasper et al. (1990) found a significantly lower increase in prolactin with fenfluramine challenge after treatment. Although this paper does not report the absolute peak levels of prolactin response or the baseline prolactin levels (only peak minus baseline), it appears from the graphic representations that there is an increase in prolactin baseline after treatment and no clear increase in the peak response (data not shown). Kasper et al. (1990) found no significant difference between the group of patients receiving the SSRI fluvoxamine and those receiving maprotiline which is primarily noradrenergic. O'Keane et al. (1992), however, found an increase in prolactin response to fenfluramine challenge after treatment with amitriptyline and fluoxetine but not with ECT.

In contrast, Shapira et al. (1989) has shown enhanced prolactin response to fenfluramine challenge after three weeks of treatment with imipramine, after treatment with clomipramine, but not clomipramine plus lithium (Shapira et al. 1992a), and after treatment with ECT (Shapira et al. 1992b). Our study showed no significant change in the post-treatment prolactin response to fenfluramine as compared to the pre-treatment prolactin response. Our results are most similar to the ones of Kasper et al. (1990), whose data also show an increased baseline. It is difficult to interpret the meaning of the other studies in terms of treatment effect on the serotonergic system. ECT decreased blunting in the study of Shapira et al. (1992b) and not in the one of O'Keane et al. (1992), and the addition of lithium to clomipramine, which should further enhance serotonergic functioning, appears to have reversed the effect of clomipramine.

\section{Relationship between Clinical Response and Pre-treatment Prolactin Response to Fenfluramine}

Some studies (Cleare et al. 1998; Kasper et al. 1990) using serotonergic and noradrenergic treatments have shown treatment response to be unrelated to prolactin response to pre-treatment fenfluramine challenge. We, on the other hand, have previously reported that patients who had a high (non-blunted) prolactin response were more likely to respond to antidepressant treatment both serotonergic and noradrenergic (Malone et al. 1993). For the current study, we used an SSRI exclusively, which we hypothesized would show an even stronger relationship between pre-treatment fenfluramine challenge and treatment response since both challenge test and treatment involved the serotonin system. We did not find predictive value in the pre-treatment challenge in this study.
Our findings agree with those of Park et al. (1995), the only other study to use fenfluramine challenge to predict response to exclusively SSRI treatment. Perhaps the small sample size and smaller male/female ratio explains not finding pre-treatment prolactin response to be predictive of clinical outcome in our current study. Also possible is the independence of SSRI responsivity from pre-treatment serotonergic function.

\section{Relationship between Clinical Response and Post-treatment Prolactin Response to Fenfluramine}

We compared treatment responders to treatment nonresponders using a post-treatment fenfluramine challenge and found that the two groups did not differ. This is consistent with most of the literature; Kasper et al. (1990), O'Keane and Dinan (1991), and Shapira et al. $(1989,1992 a, b)$ all found that prolactin response did not correlate with clinical response. In contrast, Leatherman et al. (1993) found that treatment responders did mount greater prolactin responses to CMI challenge after treatment. However, three of the six patients that were classified as responders (out of a total of 13 patients) had diagnoses other than Major Depression, and the responders had lower HDRS scores prior to treatment as compared to the non-responders.

It is possible that our finding is related to lack of power. We have previously reported that in subjects under the age of 30 , depressed subjects have a more blunted response than normal volunteers (Mann et al. 1995). We used that data as an estimate of the possible differences that might be observed in nonresponders compared to responders, respectively. We calculate that with seven responders with population mean of 22.7 $\mathrm{ng} / \mathrm{ml}$ and standard deviation of $9.5 \mathrm{ng} / \mathrm{ml}$, and nine nonresponders with population mean of $14 \mathrm{ng} / \mathrm{ml}$ and a standard deviation of $6.6 \mathrm{ng} / \mathrm{ml}$, the probability of detecting the difference in means with a one-sided, two sample t-test with alpha $=0.05$ is $61 \%$. However, it is unlikely that the difference between depressed subjects that do or do not respond to SSRI is as great as that between normal volunteers and depressed subjects, so that this probability is possibly overestimated.

There are a number of methodological concerns that must be taken into account. Our study lacks a healthy volunteer comparison group so it is not clear that the group of depressed patients has a blunted prolactin response to fenfluramine challenge when compared to healthy volunteers. However, the mean prolactin response to fenfluramine challenge of $8.4 \mathrm{ng} / \mathrm{ml}$ would place these subjects in a blunted group when compared to the subjects and controls in one of our earlier studies (Mann et al. 1995).

Our relatively small sample size is also a limitation because other studies (Mann et al. 1995) have shown subpopulations (younger women) to have a more blunted 
prolactin response to fenfluramine challenge when depressed, compared to older depressed patients. Furthermore our small sample size allowed us only to conclude that we were not able to predict clinical response by pretreatment challenge test. Wald confidence limits (0.005 and 12.324) with an odds ratio of 0.259 allows that with a greater sample size, prediction of clinical response cannot be ruled out. However, since fenfluramine has been removed from the market it would be difficult to increase the sample size to address this.

In order to maximize our sample size we elected to include the patients who were subsequently rediagnosed with bipolar depression. There is clear evidence that serotonergic function is disturbed in both unipolar and bipolar depression but no studies have focused exclusively on bipolar depression using drug challenge paradigms (Oquendo and Mann 2000). It is possible, therefore, that our data is affected by including both groups of depressed patients.

Although the mean treatment time for non-responders was greater than ten weeks, it is also possible that with continued treatment with paroxetine some of the non-responders would have become responders.

A number of studies have investigated the mechanism of fenfluramine effect on prolactin with particular interest in post-synaptic 5-HT receptors (Coccaro et al. 1996a,b, 1998; Goodall et al. 1993; Park and Cowen 1995). At least in part, prolactin response to fenfluramine challenge seems to be mediated by post-synaptic 5-HT2A/2C receptors (Coccaro et al. 1996a; Goodall et al. 1993). Our findings suggest that depression that is responsive to treatment by an SSRI is not distinguishable from treatment resistant depression by a 5-HT2A / $2 \mathrm{C}$ receptor difference in responsivity as measured by fenfluramine challenge, nor is successful treatment marked by an increase in the functioning of these receptors. Baseline prolactin release is also mediated at least in part by the 5-HT1A receptor (Cowen and Sargent 1997). Pindolol, a 5-HT1A antagonist, has been shown to lower baseline prolactin levels but not to attenuate the prolactin response to fenfluramine challenge (Park and Cowen 1995). This effect is likely to be due to blockade of postsynaptic 5-HT1A receptors, not autoreceptors. Our results are consistent with the possibility that treatment by SSRI's increases "resting" serotonergic activity, perhaps via desensitization/down regulation of 5-HT1A somatodendritic autoreceptors (Blier et al. 1997).

We have reported (Flory et al. 1998) that unmedicated non-depressed adults with a history of major depression more than one year earlier have a blunted prolactin response to fenfluramine challenge as compared to nondepressed adults with no history of depression, suggesting that reduced prolactin response to fenfluramine is a biological trait that does not change with clinical recovery. This neuroendocrine trait, in our current study, did not identify a subset of depressed patients that respond to SSRI treatment. Perhaps better tests of serotonergic function in the future will allow us to predict preferential response to serotonergic treatments or perhaps response to serotonergic treatments is more dependent on the state of other neurotransmitter systems.

\section{ACKNOWLEDGMENTS}

The authors wish to thank Monique Richards, BA and Beth Brodsky, Ph.D. This work was supported by NIMH grants $\mathrm{MH}-46745$ and $\mathrm{MH}-40695$.

\section{REFERENCES}

Asnis GM, Eisenberg J, van Praag HM, Lemus CZ, Harkavy Friedman JM, Miller AH (1988): The neuroendocrine response to fenfluramine in depressives and normal controls. Biol Psychiatry 24:117-120

Blier P, Bergeron R, De Montigny C (1997): Selective activation of postsynaptic $5-\mathrm{HT}_{1 \mathrm{~A}}$ receptors induces rapid antidepressant response. Neuropsychopharmacology 16:333-338

Charney DS, Heninger GR, Sternberg DE (1984): Serotonin function and mechanism of action of antidepressant treatment. Effects of amitriptyline and desipramine. Arch Gen Psychiatry 41:359-365

Cleare AJ, Murray RM, O'Keane V (1998): Assessment of serotonergic function in major depression using $d$-fenfluramine: Relation to clinical variables and antidepressant response. Biol Psychiatry 44:555-561

Coccaro EF, Kavoussi RJ, Cooper TB, Hauger R (1996b): 5- $\mathrm{HT}_{3}$ receptor antagonism by ondansetron does not attenuate prolactin response to $d$-fenfluramine challenge in healthy human subjects. Psychopharmacology 127:108-112

Coccaro EF, Kavoussi RJ, Cooper TB, Hauger R (1998): Acute tryptophan depletion attenuates the prolactin response to $d$-fenfluramine challenge in healthy human subjects. Psychopharmacology 138:9-15

Coccaro EF, Kavoussi RJ, Oakes M, Cooper TB, Hauger R (1996a): 5-HT $\mathrm{Ha}_{2 \mathrm{ac}}$, receptor blockade by amesergide fully attenuates prolactin response to $d$-fenfluramine challenge in physically healthy human subjects. Psychopharmacology (Berl) 126:24-30

Coccaro EF, Siever LJ, Klar HM, Maurer G, Cochrane K, Cooper TB, Mohs RC, Davis KL (1989): Serotonergic studies in patients with affective and personality disorders. Correlates with suicidal and impulsive aggressive behavior. Arch Gen Psychiatry 46:587-599

Cowen PJ, Sargent PA (1997): Changes in plasma prolactin during SSRI treatment: evidence for a delayed increase in 5-HT neurotransmission. J Psychopharmacol 11:345-348

Flory JD, Mann JJ, Manuck SB, Muldoon MF (1998): Recovery from major depression is not associated with normalization of serotonergic function. Biol Psychiatry 43:320-326

Goodall EM, Cowen PJ, Franklin M, Silverstone T (1993): 
Ritanserin attenuates anorectic, endocrine and thermic responses to $d$-fenfluramine in human volunteers. Psychopharmacology 112:461-466

Gordon C, Whale R, Cowen PJ (1998): Sertraline treatment does not increase plasma prolactin levels in healthy subjects. Psychopharmacology 137:201-202

Kasper S, Vieira A, Schmidt R, Richter P (1990): Multiple hormone responses to stimulation with $d l$-Fenfluramine in patients with major depression before and after antidepressive treatment. Pharmacopsychiatry 23:76-84

Laine K, Anttila M, Heinonen E, Helminen A, Huupponen R, Mäki-Ikola O, Reinikainen K, Scheinin M (1997): Lack of adverse interactions between concomitantly administered selegiline and citalopram. Clin Neuropharmacol 20:419-433

Leatherman ME, Ekstrom RD, Golden RN (1993): Central serotonergic changes following antidepressant treatment: A neuroendocrine assessment. Psychopharmacol Bull 29:149-154

Lesch KP (1991): The ipsapirone/5- $\mathrm{HT}_{1 \mathrm{~A}}$ receptor challenge in anxiety disorders and depression. Excerpta Med Int Congress Series 968 2:905-908

Lichtenberg P, Shapira B, Gillon D, Kindler S, Cooper TB, Newman ME, Lerer B (1992): Hormone responses to fenfluramine and placebo challenge in endogenous depression. Psychiatry Res 43:137-146

Lopez-Ibor JJ Jr, Saiz-Ruiz J, Iglesias LM (1988): The fenfluramine challenge test in the affective spectrum: A possible marker of endogeneity and severity. Pharmacopsychiatry 21:9-14

Maes M, Meltzer HY (1995): The serotonin hypothesis of major depression. In Bloom FE, Kupfer DJ (eds), Psychopharmacology: The Fourth Generation of Progress. New York, Raven Press, pp 933-944

Malone KM, Corbitt EM, Li S, Mann JJ (1996): Prolactin response to fenfluramine and suicide attempt lethality in major depression. Br J Psychiatry 168:324-329

Malone KM, Thase ME, Mieczkowski T, Myers JE, Stull SD, Cooper TB, Mann JJ (1993): Fenfluramine challenge test as a predictor of outcome in major depression. Psychopharmacol Bull 29:155-161

Mann JJ, Malone KM, Diehl DJ, Perel J, Cooper TB, Mintun MA (1996): Demonstration in vivo of reduced serotonin responsivity in the brain of untreated depressed patients. Am J Psychiatry 153:174-182

Mann JJ, McBride PA, Malone KM, DeMeo MD, Keilp J (1995): Blunted serotonergic responsivity in depressed patients. Neuropsychopharmacology 13:53-64

McBride PA, Tierney H, DeMeo M, Chen J-S, Mann JJ (1990): Effects of age and gender on CNS serotonergic responsivity in normal adults. Biol Psychiatry 27:1143-1155

Mitchell P, Smythe G (1990): Hormonal responses to fenfluramine in depressed and control subjects. J Affect Disord 19:43-51

Mokrani M-C, Duval F, Crocq MA, Bailey P, Macher JP (1997): HPA axis dysfunction in depression: Correlation with monoamine system abnormalities. Psychoneuroendocrinology 22(Suppl 1):S63-S68

O'Keane V, Dinan TG (1991): Prolactin and cortisol responses to $d$-fenfluramine in major depression: Evidence for diminished responsivity of central serotonergic function. Am J Psychiatry 148:1009-1015

O'Keane V, McLoughlin D, Dinan TG (1992): D-fenfluramine-induced prolactin and cortisol release in major depression: Response to treatment. J Affect Disord 26:143-150

Oquendo MA, Mann JJ (2000): Serotonergic dysfunction in mood disorders. In Soares JC, Gershon S (eds), Bipolar Disorders. New York, Marcel Dekker, Inc., pp 121-142

Park SBG, Cowen PJ (1995): Effect of pindolol on the prolactin response to $d$-fenfluramine. Psychopharmacology 118:471-474

Park SBG, Williamson DJ, Cowen PJ (1995): Do the endocrine and subjective effects of $d$-fenfluramine predict response to selective serotonin reuptake inhibitors? Int Clin Psychopharmacol 10:215-220

Park SBG, Williamson DJ, Cowen PJ (1996): 5-HT neuroendocrine function in major depression: prolactin and cortisol responses to D-fenfluramine. Psychol Med 26:1191-1196

Quested DJ, Sargent PA, Cowen PJ (1997): SSRI treatment decreases prolactin and hyperthermic responses to mCPP. Psychopharmacology 133:305-308

Shapira B, Cohen J, Newman ME, Lerer B (1993): Prolactin response to fenfluramine and placebo challenge following maintenance pharmacotherapy withdrawal in remitted depressed patients. Biol Psychiatry 33:531-535

Shapira B, Lerer B, Kindler S, Lichtenberg P, Gropp C, Cooper T, Calev A (1992b): Enhanced serotonergic responsivity following electroconvulsive therapy in patients with major depression. Br J Psychiatry 160:223-229

Shapira B, Reiss A, Kaiser N, Kindler S, Lerer B (1989): Effect of imipramine treatment on the prolactin response to fenfluramine and placebo challenge in depressed patients. J Affect Disord 16:1-4

Shapira B, Yagmur MJ, Gropp C, Newman M, Lerer B (1992a): Effect of clomipramine and lithium on fenfluramine-induced hormone release in major depression. Biol Psychiatry 31:975-983

Siever LJ, Murphy DL, Slater S, de la Vega E, Lipper S (1984): Plasma prolactin changes following fenfluramine in depressed patients compared to controls: An evaluation of central serotonergic responsivity in depression. Life Sci 34:1029-1039

Sommers DK, Van Wyk M, Synman JR (1994): Dexfenfluramine-induced prolactin release as an index of central synaptosomal 5-hydroxytryptamine during treatment with fluoxetine. Eur J Clin Pharmacol 46:441-444

Spigset O, Mjörndal T (1997): The effect of fluvoxamine on serum prolactin and serum sodium concentrations: Relation to platelet 5- $\mathrm{HT}_{2 \mathrm{~A}}$ receptor status. J Clin Psychopharmacol 17:292-297

Spitzer RL, Williams JBW, Gibbon M, First MB (1989): Instruction Manual for the Structured Clinical Interview for DSM-III-R (SCID, 5/1/89 Revision). New York, Biometrics Research Department, New York State Psychiatric Institute

Urban RJ, Veldhuis JD (1991): A selective serotonin reuptake 
inhibitor, fluoxetine hydrochloride, modulates the pulsatile release of prolactin in postmenopausal women. Am J Obstet Gynecol 164:147-152

Weizman A, Mark M, Gil-Ad I, Tyano S, Laron Z (1988): Plasma cortisol, prolactin, growth hormone, and immunoreactive beta-endorphin response to fenfluramine challenge in depressed patients. Clin Neuropharmacol 11:250-256

Wing Y-K, Clifford EM, Sheehan BD, Campling GM, Hockney RA, Cowen PJ (1996): Paroxetine treatment and the prolactin response to sumatriptan. Psychopharmacology 124:377-379 